\title{
Potential agricultural and environmental benefits of mulches-a review
}

\author{
Rashid Iqbal' (D), Muhammad Aown Sammar Raza ${ }^{1 *}$, Mohammad Valipour ${ }^{2}$, Muhammad Farrukh Saleem³ \\ Muhammad Saqlain Zaheer ${ }^{1}$, Salman Ahmad', Monika Toleikiene ${ }^{4}$, Imran Haider ${ }^{1}$, Muhammad Usman Aslam \\ and Muhammad Adnan Nazar ${ }^{1}$
}

\begin{abstract}
Rapid industrialization and urbanization have resulted in elevated global temperature over the years consequently disturbing the balance of agro-ecological systems worldwide. Therefore, new eco-friendly agricultural practices for sustainable food production are needed. Mulching could potentially serve the purpose by reducing soil evaporation, conserving moisture, controlling soil temperature, reducing weed growth, and improving microbial activities. Additionally, mulches could provide economical, aesthetic, and environmental advantages to agriculture and landscape. Moreover, in the restoration sites, mulches are widely used for the plantation of trees which need no significant care. Mulches combat with different stress conditions in agricultural lands as well as in landscapes. This review paper focuses on multiple significant impacts of mulches for the production and establishment of different crops in nature. Mulches conserve the soil moisture, enhance the nutrients status of soil, control the erosion losses, suppress the weeds in crop plants, and remove the residual effects of pesticides, fertilizers, and heavy metals. Mulches improve the aesthetic value of landscapes and economic value of crops. This paper also describes some problems associated with various mulch materials. There are contradictions about mulching materials as some researchers favor mulches and others have denoted some concerns. The selection of mulching material is important with respect to crop type, management practices, and climatic conditions. The appropriate mulching technique could provide the aforementioned benefits to the agro-ecological systems. Therefore, the impacts of low-cost, eco-friendly, and biodegradable mulching materials on soil microbes, nutrient balance, plant growth, and soil erosion should be explored in the future.
\end{abstract}

Keywords: Organic mulch, Inorganic mulch, Mulch management, Landscapes establishment, Residual reduction of pesticides \& chemicals, Soil health

\section{Introduction}

The word mulch has been derived from the German word molsch means "easy to decay," and mulches have widely been used for vegetable production since ancient times (Lightfoot 1994). Mulching is referred as spreading various covering materials on the surface of soil to minimize moisture losses and weed population and to enhance crop yield (Nalayini 2007; Kader et al. 2019).

\footnotetext{
*Correspondence: scorpio.rana786@gmail.com

'Department of Agronomy, University College of Agriculture \&

Environmental Sciences, The Islamia University of Bahawalpur, Bahawalpur,

Pakistan

Full list of author information is available at the end of the article
}

Mulches could potentially minimize water runoff, improve infiltration capacity of soil, restrain weed population via shading, and perform as obstacle in evapotranspiration (Rathore et al. 1998). Mulching has also some other positive environmental effects such as temperature regulation of soil and plant roots, minimum nutrient losses, cut down soil erosion and compactness, and improved physical conditions of soil (Ngouajio and McGiffen 2004; Lamont 2005).

Mulches got attention in the late 1930, as these materials can alter the surrounding conditions of agricultural lands, forest areas, and horticultural lands. Some earlier 
studies showed a number of damaging effects caused by mulches (Bedford and Pickering 1919). In 1941, deep mulches were also used for trees and shrub plantation (Pirone 1941) because these deep-type mulches give protection to drought stress such as frost injury and freezing damage of crop plants in harsh environmental conditions. More water conservation was achieved when the same quantity of mulch material was used as mulch compared with that incorporated into the soil (Singh et al. 1991). The by-products of agricultural and forestry domains have been used as mulches in the mid 1900s century (Clifford and Massello 1965). However, some other materials were also used as mulch such as trimmings of trees and shrubs, wastes of animals, stubbles, and residues of crop plants. Landscape mulches were also seen in 1957 but there was no scientific research work carried out on them (Anonymous 1957).

Mulches could be of both organic and synthetic (inorganic) origin. The organic mulches consist of animal and plant residues. The most commonly used organic mulches include straws, husks, grasses and cover crops (live mulches), saw dust, compost, and manures (Rathore et al. 1998), while the most frequently used inorganic mulch throughout the world is polyethylene plastic mulch. The application of plastic mulching in agriculture is getting popular throughout the world, and its usage is increasing day by day. In 1999, plastic mulch was used on an area of more than 22 million hectares of cultivated land worldwide (Miles et al. 2005). In 2002, plastic mulch was spread on an area of 15 million hectares in China (Xing et al. 2003). On an average, 700,000 tons of plastic sheet are being used annually as mulch worldwide (Espi et al. 2006) and 140,000 tons in USA alone (Shogren 2001).The black plastic mulch is generally used in agricultural lands globally (Schales 1990). Utilization of black plastic mulch is mostly due to its low prices in relation to other mulches (Ngouajio and McGiffen 2004). Mulches are very supportive in the commercial crop production on a regular basis in dry and hot regions of the world. Consequently, finding out the effects of mulching (both long and short term) on cultivated lands to handle the weeds and water deficiency problems is needed (Schahbazian and Nejad 2006; Kader et al. 2019).

The literature review shows that application of mulches has been addressed; however, to the best of our knowledge, there is no study in which advantages and disadvantages of mulches in agriculture and the environment have been comprehensively reviewed. Therefore, this study aims to present potential agricultural and environmental benefits of mulches with respect to an overview on past investigations.

\section{Potential advantages of mulching in agriculture Soil moisture conservation}

Many abiotic factors are responsible for the loss of moisture from the soil and converting it into barren land.
These variables could be high winds, elevated temperature levels, harsh climatic conditions, and competing plantation such as weeds. It has been estimated that presence of weeds could result in loss of water up to $25 \%$ due to evapotranspiration (Harris et al. 2004). Mulches can potentially reduce weed infestation and evaporation losses and enhance the percolation and retention rate of soil. It was reported that straw mulch can decrease the rate of evaporation by 35\% (Russell 1939). Likewise, Kacinski (1951) reported that non-living mulch materials had greatest capability in moisture conservation in soil as compared to un-mulched soil. A few of the potential advantages of mulching have been presented in Fig. 1 .

The organic mulches have attained greater value than the inorganic mulches in agricultural lands, as the organic mulches could increase the percolation and water retention of soil. Organic and inorganic mulches can better conserve the soil water as compared to synthetic (Arthur and Wang 1999) and barren (Lakatos et al. 2000) soil. Generally, the livestock wastes, residues of crop plants, and different types of stone gravels are used as mulch materials to retain the soil moisture (Siipilehto 2001; Buban et al. 1996). Moreover, mulches have more benefits over the cover crops as the cover crops are considered as the competitor of the main crop of interest and compete for water resources (Downer and Hodel, 2001).

Mulches can reduce the irrigation requirement of crop plants, and sometimes, they can totally finish the need of irrigation (Ahmad et al. 2015; Kader et al. 2019; Iqbal et al. 2019; Ahmad et al. 2020). Some organic mulch act as sponge and retain rainfall and irrigation water thus protecting the runoff and provides water at the time of crop requirement. The runoff was reduced by $43 \%$ through using the straws as mulch (Borst and Woodburn 1942). Supplemental irrigation is lowered by mulches because of their water retention ability, simultaneously reducing the runoff of soil profile (Smith 2000).

\section{Minimizing soil compaction and erosion}

The mulching materials protect the soil from wind and water erosion phenomenon and reduce the compaction of soil which can badly affect the roots of crops consequently reducing the growth and development of plants. Growing grass is the best example of living mulch on the slopes which reduces the soil erosion by aggregating the soil particles by binding in a complex unit (Tanavud et al. 2001). Sartz (1963) used the barley crop as the living mulch material. According to Borst and Woodburn (1942), using a thin layer of 0.6 inches of mulch could reduce the erosion of about $86 \%$. Straws and other residues of cereal crops are most commonly used for the reduction of the soil erosion (Samarappuli and Yogaratnam 


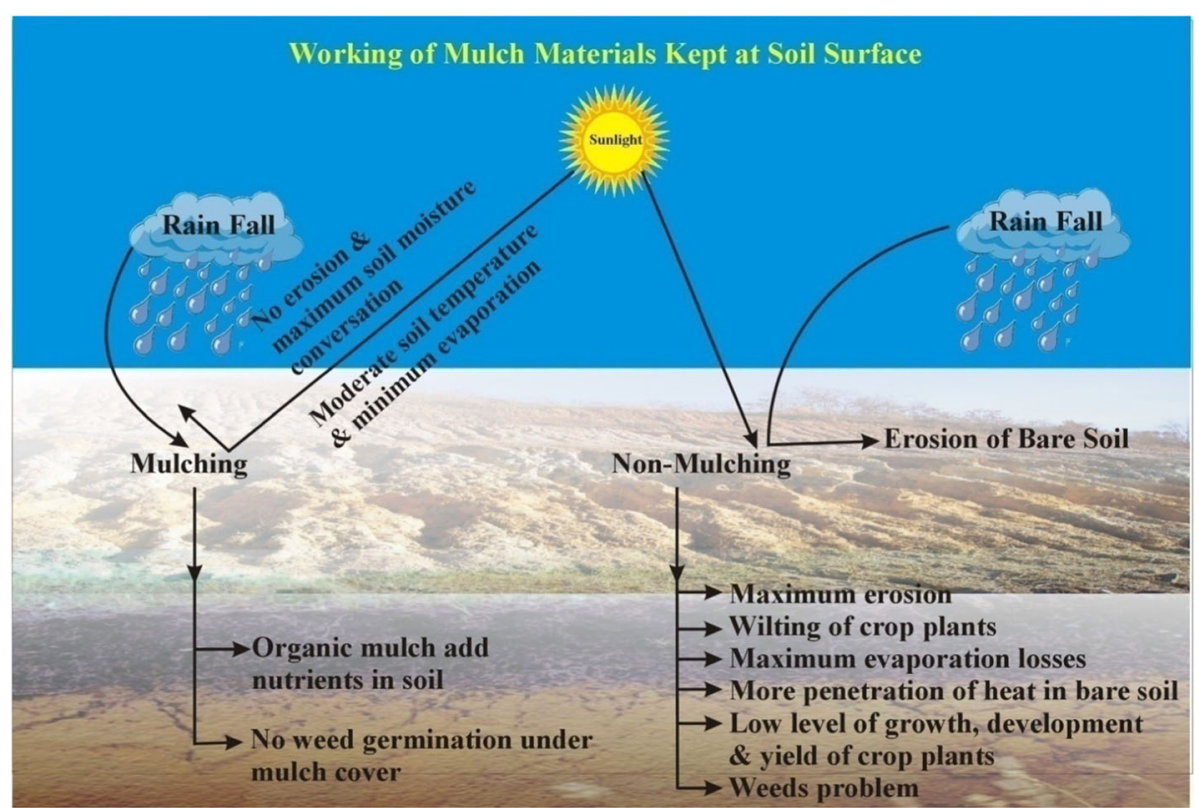

Fig. 1 Advantages of mulching in comparison to non-mulching

1984). Some grasses and legumes have also been used as living mulch (Samarappuli and Yogaratnam 1984; Tanavud et al. 2001). The combined use of straw mulch and erosion net was found to decrease the soil erosion by 95\% in comparison to the barren soil in forest areas (Megahan 1974). The needle-like leaves of pinus have been found helpful to reduce erosion losses (McCambridge et al. 1982), and pinus sticks debris was used to control runoff and erosion losses successfully (Rothwell 1978). Mulch materials immediately break the speed of water in hilly areas and increase the infiltration rate of soil, and to maintain the slope stabilization, engineering techniques must be used instead of merely dependent on mulching method (Chalker-Scott 2007).

The problem of compaction due to the heavy implements or machinery is getting severe in many agricultural lands (Chalker-Scott 2007). The problem of compaction can be solved with the addition of organic mulch materials such as bark (Oliveira and Merwin 2001). The mulch material can reduce the beating action of rain drops or alleviate the heavy weight of feet and tires of heavy implements. It was suggested that mulching should be performed before the development of soil compaction, as once compaction was developed, there will be no significant improvement in soil aggregation with mulching (Donnelly and Shane 1986).

\section{Regulation of soil temperature}

Mulching covers the soil surface, and hence, it is helpful in maintaining the soil temperature which is beneficial for overall crop growth. Many studies demonstrated that the application of mulch could keep the soil cool during very hot climatic conditions (Kader et al. 2019; Long et al. 2001; Einert et al. 1975; Fraedrich and Ham 1982), while at normal/warm temperature in chilling days (Kudinov 1972; Kader et al. 2019). The temperature extremes affect the newly growing roots of plants adversely reducing the uptake of nutrients and water (Goulet 1995). The extreme temperature condition under early growth stages of plants may cause the plants to go under stress conditions as newly established roots are not able to uptake the proper amount of water and essential plant nutrients (Chalker-Scott 2007). Therefore, the judicious maintenance and regulation of soil temperature is a very critical factor for optimum plant growth. However, in hot and dry conditions such as in deserts, mulches decrease the temperature by $10^{\circ} \mathrm{C}$ (barren soil) (Martin and Poultney 1992).

The selection of specific mulching type for particular purpose is of significant importance. For instance, coarse mulches are more beneficial than the finer ones of the same category in controlling the temperature at favorable conditions (Horowitz and Thomas 1994). Various types of mulches have different effects on soil temperature. Some mulches increase the soil temperature as compared to the barren soil or living mulches due to absorption of solar radiation (Montague and Kjelgren 2004). Tilander and Bonzi (1997) reported that the cobbles mulch had more positive effects than the gravel mulch, and leaf mulches had greater optimistic effects than the compost material. Likewise, Van Nierop and White (1958) reported that the heavy or thicker application of mulches has more positive impacts on temperature maintenance as compared to thin 
mulch application on soil surface. Moreover, it has been observed that living mulch and organic mulch materials are far better in maintaining the favorable soil temperature compared to other mulch materials (Walsh et al. 1996; Iles and Dosmann 1999; Martin and Poultney 1992; Montague and Kjelgren 2004). The turf mulch (living mulch) liberates more water vapors through the evapotranspiration process and decrease the soil surface temperature due to its evaporative cooling effect (Montague and Kjelgren 2004) despite the fact that turf mulch uses more water of soil in relation to the non-living mulch materials. Among the inorganic mulches, the gravel mulch is more temperature moderating than the solid-type mulch such as concrete (Iles and Dosmann 1999; Montague and Kjelgren 2004). Synthetic mulches (plastics, fabrics and asphalt) have been reported as inefficient in temperature regulation as these could increase the soil temperature instead of controlling at the favorable level (Duncan et al. 1992; Litzow and Pellett 1993; Montague and Kjelgren 2004; Walsh et al. 1996; Chalker-Scott 2007; Kader et al. 2019). Besides synthetic mulches, some of the other types of mulches have also been observed as inefficient in soil temperature regulation. For instance, pine bark mulching increased the soil surface temperature which affected the nearest leaves to transpire more water through the leaves (Zajicek and Heilman 1994).

\section{Soil fertility improvement}

The organic and living mulches possess numerous beneficial impacts on soil quality in terms of enhancing nutrients levels. However, the type of the material, soil characteristics, and climatic conditions determine the increase, decrease, or no effect on soil nutrients. The application of organic mulches is more beneficial because these can be decomposed in an appropriate environment, providing the nutrients as described in Fig. 2. Different studies demonstrated that wood chips, straw, green manures, and bark mulches provide more nutrients as compared to inorganic mulches (Ansari et al. 2001; Downer and Hodel 2001; Pickering and Shepherd 2000; Singh et al. 1991). However, the organic mulches with higher nutrient supply capability are mostly used for the landscaping, as the extensive application of these mulches to agricultural lands can damage the sensitive crops, living organisms, and water resources. Therefore, the mulches with higher ability of providing nutrients must be managed properly (Chalker-Scott 2007). Niggli et al. (1988) reported that un-composted bark or straw (low-nutrient mulches) reduced the nitrogen content of soil without affecting the plant nutrition, resulting in reduced pollution of watershed. Mulches having high nitrogen content increase the yield of crop plants (Tilander and Bonzi, 1997). Mulches having low nitrogen

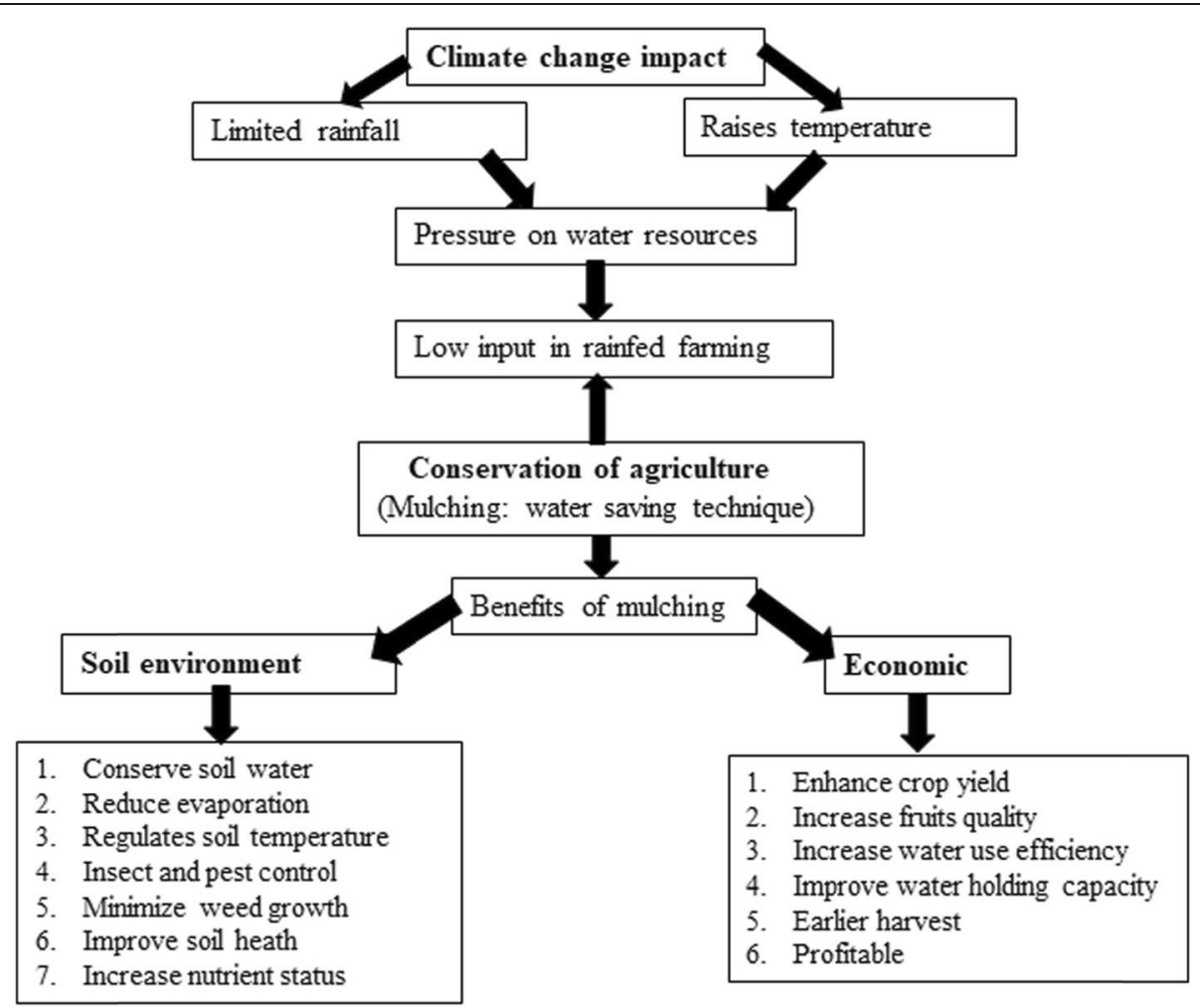

Fig. 2 Schematic diagram of the conservation agriculture interacts with climate and crop (Kader et al. 2019) 
in them can also increase the nutrition of plants and fertility of soil, e.g., straw mulch (Szwedo and Maszczyk 2000), sawdust mulch (Arthur and Wang 1999), and bark mulch (Pfammatter and Dessimoz 1997), are capable of increasing nutrient levels in foliage as well as in soil. Husk mulched are found to be most effective in increasing the nutrient levels in soil as compared to leaf or grass mulch with higher nitrogen content (Singh and Singh 1999). Water hyacinth as a potential organic substrate can stimulate the growth of diversity of microbial population in agricultural soils. In general, soil respiration and microbial population were significantly greater in mulched plots compared to control. Among treatments, vermicompostmulched plots were recorded for higher bacterial and fungal counts at both surface and sub-surface soil layers (Balasubramanian et al. 2013).

\section{Mitigation of salt stress}

Healthy soils could ensure sustainable crop production for food security. However, due to anthropogenic perturbations and various other factors, the problem of soil salinity is increasing day by day by covering about one third of the land surface. Misuse and mismanagement of these soils results in soil erosion, reduction in crop productivity, lower soil water holding capacity, a decline in soil biodiversity, and, ultimately, desertification and loss of carbon. Irrigating the plants with untreated water from municipal wastes water with high levels of salts may pose harmful effects on crop growth and development. Moreover, the extensive use of synthetic fertilizers, pesticides, detergents, and some other chemicals may add salts to the soils to substantial levels (Chalker-Scott 2007). The mulching could affectively solve the salinity problem by enhancing water retention in soil and reducing evapotranspiration. Various studies exhibited that the effect of salts toxicity was reduced with mulching (Ansari et al. 2001; Landis 1988; Yobterik and Timmer 1994). Organic mulches have been observed as more helpful for the reclamation of soil and induce the desalinization of soil (Dong et al. 1996). Organic mulches can be decomposed by the microbes resulting in the degradation of many harmful residues and lessens the salt contamination (Gan et al. 2003; Smith and Skroch 1995). However, the plastic mulches are not commonly used for the mitigation of salts (Sun et al. 1994).

\section{Plant growth, development, and yield}

Mulching materials are widely used for the establishment of many herbs and tree species. There are many research studies which showed the positive impacts of mulches on the germination, survival of newly grown plants, and transplantation of seedlings and overall performance of crop plants in relation to un-mulched treatments (Table 1). In this way, mulching is favorable for maximum yield with very low input resources (ChalkerScott 2007; Ahmed et al. 2013; Kwambe et al. 2015; Kader et al. 2019). Straw mulching combined with wideprecision planting is a suitable measure to compensate winter wheat grain yield reduction and increase grain quality (Ahmad et al. 2015; Tan et al., 2019; Iqbal et al. 2019; Ahmad et al. 2020). The adoption of the planting basin tillage under sorghum stover mulching, a technology designed for smallholder farmers with limited access to animal draft power, can improve considerably the

Table 1 The improvement in the economic yield of various crops due to mulching

\begin{tabular}{|c|c|c|c|c|}
\hline \multirow[t]{2}{*}{$\overline{C r o p}$} & \multicolumn{2}{|c|}{ Economic yield tons ha ${ }^{-1}$} & \multirow[t]{2}{*}{$\%$ Increase in yield } & \multirow[t]{2}{*}{ References } \\
\hline & Un-mulched & Mulch & & \\
\hline Tomato & 6.02 & 8.27 & 27.20 & Moursy et al. (2015) \\
\hline Chickpea & 5.91 & 7.32 & 19.26 & Fetri et al. (2015) \\
\hline Cotton & 1.67 & 2.22 & 24.77 & Ahmad et al. (2015) \\
\hline Mustard & 0.41 & 0.61 & 32.78 & Saikia et al. (2014) \\
\hline Rice & 5.39 & 6.83 & 21.08 & Devasinghe et al. (2015) \\
\hline Lentil & 0.80 & 0.89 & 10.11 & Alami-Milani et al. (2013) \\
\hline Maize & 2.49 & 4.76 & 47.68 & Hashim et al. (2013) \\
\hline Mung beans & 1.02 & 1.36 & 25.00 & Jiang et al. (2012) \\
\hline Soybean & 1.32 & 1.57 & 15.92 & Arora et al. (2011) \\
\hline French beans & 12.73 & 14.10 & 9.71 & Kamal et al. (2012) \\
\hline Potato & 24.00 & 30.00 & 20.00 & Dvorak et al. (2009) \\
\hline Barley & 3.77 & 4.27 & 11.70 & Malecka and Blecharczyk (2008) \\
\hline Wheat & 7.24 & 7.79 & 7.06 & Yang et al. (2006) \\
\hline
\end{tabular}


dry-land sorghum grain yield and weight of 1000 kernels (Masaka et al. 2019). According to Table 1, mulching can increase agricultural yield from 7 to $47 \%$ based on the results obtained in the past studies. The highest rate of increase belongs to maize, while wheat shows the lowest rate of increase.

An experiment was conducted on oak species with mulching pits in comparison to the control treatment. Manures and sawdust mulches were used for seedling survival of oak species. Outcomes of the study showed the significant effect of germination and seedling survival in relation to the pits with surface plantings using no mulch material (Kacinski 1951). Weeds are a serious agricultural problem and reduce the yield of many crop plants globally. Mulches reduce the survival of every plant which comes under the mulch surface. They are not capable of differentiating between the desired plant and weed species. Mulches have the ability to reduce the population of weed species (Chalker-Scott 2007; Kader et al. 2019).

Mulch depth and seedling age are necessary for the proper establishment and survival of transplanted seedlings. Deeper mulches can better control the weed population, but these are not as effective in areas which are grown with smaller seeds. When the mulch material is used after the broadcasting of seeds, a thin layer is most effective as compared to heavy mulch application before seeding of smaller seeds (Rokich et al. 2002). Organic or live mulches are most favorable than the gravel or stone mulches for proper seed germination (Montano et al. 1977) which can inhibit the germination of seeds in deeper layers of soil (Winkel et al. 1995). After the emergence of seedlings from the soil surface, mulches can enhance their performance in field (Naklang et al. 1999) and nursery conditions (Mishra et al. 1996; Tisserat and Kuntz 1984). Mulch materials reduce the evaporation losses, in this way enhancing the water retention in soil and helpful in reduction of weed species. This is also achieved by mulches via increasing the root establishment, growth, and development (Fausett and Rom 2001; Wood 1994). Mulches permit the desired crop plant to extend its root system far away from the main trunk as compared to the un-mulched barren soil. In this way, mulched plants get more biomass and more heighted (Burgess et al. 1997; Watson 1988).

In the selection of mulch material, it is very imperative to know how much soil will be explored by mulching. Greatest root development and density was achieved using organic mulches in relation to plastic mulch (Fausett and Rom 2001), un-mulched soil (Watson 1988), and living mulch material (Green and Watson 1989). Some mulch are used as barriers of water and air movement such as sheet and film mulches which enhance the root growth above the mulch surface but when these mulches are removed, they damage the crops grown on them (Appleton et al. 1990). A research study was conducted on plastic mulch with fertilizer as an addition, and outcomes showed an increased death rate of transplanted plants (Houle and Babeux 1994).

Organic mulches are better than any other mulch materials because they provide nutrients and water to newly grown plant roots. Roots also have the ability to extend in search of water where it is easily available in the plant root zone (Watson 1988; Watson and Kupkowski 1991). If the plants' root grow successfully, then survival of plant is certain. The use of landscape mulches prevents the death of newly transplanted plants even in unfavorable environmental conditions, e.g., saline (Ansari et al. 2001; Sun et al. 1994), subarctic (Houle and Babeux 1994), and mines tailing (Munir et al. 1998; Woods et al. 1979). Increased survival of transplanted seedling was observed under field and nursery conditions (Martin and Poultney 1992; Maynard 1998; Naklang et al. 1999), silviculture farming (Samra and Singh 1998), plantations of forests (Gardiner and Yeiser 1998; Hunt 1963), and sites of restorations (Cahill et al. 2005; Zink and Allen 1998). Turf which is mostly used as a competitor cover crop increased the mortality rate of transplants (Downer and Hodel 2001).

Research studies conducted on mulch in 1942 revealed that the trees which are grown with mulch materials grew up better than the un-mulched trees (Hopp and Posey 1942). Some other scientists carried out the mulch experiments, and their outcomes were also in line with the early study of mulched trees performed better than the control treatment (Balvinder et al. 1988; Buban et al. 1996; Calkins et al. 1996; Foshee et al. 1996; Seckler and Tejwani 1983). The growth and yield parameters which were influenced by mulch materials are increased plant height (Balvinder et al. 1988; Ringe and Graves 1990; Samra and Singh 1998; Singh and Saggar 1997), stem of plant/trunk of tree diameter (Balvinder et al. 1988; Downer and Hodel 2001; Green and Watson 1989; Samra and Singh 1998; Singh and Saggar 1997), increased number or size of plant leaves (Davis 1994; Downer and Hodel 2001; Martin and Poultney 1992; Pfammatter and Dessimoz 1997), and maximum production of flowers, fruits, and seeds (Pfammatter and Dessimoz 1997; Tilander and Bonzi 1997).

The best mulch which is mostly used in field conditions is the organic mulch, and it can increase the overall performance of crop plants and also brings improvement in soil conditions. These mulches are categorized as rapid decomposers such as compost, leaves, and grass clippings (Green and Watson 1989; Pfammatter and Dessimoz 1997; Samarappuli and Yogaratnam 1984; Singh and Saggar 1997; Tilander and Bonzi 1997); moderate decomposers as paper, straw and hay (Davis 
1994; Litzow and Pellett 1993), crop residues (Martin and Poultney 1992); and slow decomposers, e.g., stem bark and woody chips (Downer and Hodel 2001; Green and Watson 1989; Ringe and Graves 1990). Sometimes, slow-decomposing mulch materials like bark mulch can make nutritional problem for fast-growing tree species due to low production of plant root biomass (Davis 1994).

For the optimization of overall plant performance, stones and gravels are not considered as better materials as the organic ones (Samra and Singh 1998; Seckler and Tejwani 1983; Singh and Saggar 1997). Sheet mulches also have no significant effect on plant performance and produce very unsatisfactory results (Litzow and Pellett 1993; Seckler and Tejwani 1983). Turf mulch which is mostly used as competitive cover crop also showed reduced growth rates (Samarappuli and Yogaratnam 1984) as compared to bare (un-mulched) conditions of soil (Downer and Hodel 2001; Kraus 1998).

\section{Diminution of diseases}

Mulching materials have the ability to reduce the evaporation losses and hence conserve the soil moisture, thus reducing irrigation water requirements. Mulches can act as barriers against irrigation water or beating action of rain drops which carry spores of different diseases. These spores attach themselves with foliage and shoots of the vulnerable plants. Mulches help in the nutrition of many beneficial organisms which competes the incoming pathogenic spores or sometimes release the chemicals for the inhibition of pathogens; in this way, they reduce the chances of disease occurrence (Chalker-Scott 2007).

There are many ways of disease reduction in plants through mulches. Spaulding and Hansbrough (1943) investigated that the needles which suffered from blight disease worked as mulch on the surface for the better growth of tree species. Mulches have a direct or an indirect mechanism to lessen the disease. This mechanism was also elaborated by Downer et al. (2002) who discovered the root rot disease through short- and long-term mulching effects. The indirect effects of mulches are helpful for the prevention of plant diseases such as improvement in nutrition of plants, better drainage, moderation of soil temperature, improved soil aggregation, and conservation of soil moisture. Consequently, mulch materials provide a healthy atmosphere for crop plants which optimize the vigorous growth and development of plants that may remain safe from the pathogenic organisms (Turchetti et al. 2003).

Organic mulches also restrain many soil microbes which directly compete or degrade the pathogenic organisms with the help of many enzymatic reactions (Crohn and Bishop 1999). The pathogens of fungus mostly contain cellulose in their cell wall which is degraded by the cellulose enzyme which is produced by most of the soil microbes which live inside the mulch (Downer et al. 2002). Mulching with the aim of maximum colonization of microbes will also be helpful for the biological control of many harmful pathogens (Entry et al. 2005). This is the main reason of reducing the diseases using organic mulches such as straw (Bowen and Behe 1995) and woodchips (Davis 1994) in relation to polyethylene and fabric mulches.

Mulches are an important part of integrated pest management (IPM). Some mulch can increase the chances of disease occurrence when used in a poor soil condition. In 1948, sawdust was used as a mulch material in gardens and it was noticed that sawdust caused root rot disease in many plant species (Matthews 1948). Black polyethylene mulch caused the bacterial soft rot disease as compared to woodchips or bark mulch (Davis 1994). Therefore, selection of the mulch material is imperative because mulches are a part of IPM plan.

\section{Decline of weeds}

Mulching is a favorable tool for controlling the weed populations in nursery as well as field conditions as illustrated in Fig. 2; however, the phenomenon of weeds reduction is not fully understood till now. Wilen et al. (1999) found that there was 92\% reduction of weed population as compared to non-mulched treatment. When mulch is spread on the soil surface, they act as barriers in the passing of light resulting in reduced germination of small-seeded weed species. Different types of mulches (15 different mulch types) were used in comparison to non-mulched, and outcomes of the study showed that there was no difference between all mulch types but a significant difference exists for reduction of weeds with bare soil treatment (Stinson et al. 1990; Mohtisham et al. 2013; Kader et al. 2019). Mulches act as physical obstacles in the emergence of weeds (Ahmad et al. 2015; Ahmad et al. 2020); however, when the organic mulches decompose, they quickly come out the soil surface. Some organic mulch also acts as the allelopathic and releases some toxic chemicals which are helpful for the reduction of weeds. Besides this, the environment that is created through the mulch is very helpful for beneficial microbes which feed on the weed species or weed seeds (Chalker-Scott 2007). Likewise, the living mulches are useful to reduce the weeds by competing for the basic resources such as light, moisture, nutrients, and oxygen. They also have the allelopathic effects on the weed species. Some cover crops and ground cover are also supportive for lessening of weed seed germination and their establishment (Griffiths and Fairhurst 2003). The quantity of mulches should be limited in field conditions, and if living mulches are used too much, then they compete for the basic resources of 
light, moisture, oxygen, and nutrients (Chalker-Scott 2007). Even though plastic films and landscape fabrics have the ability to successfully reduce the weed population, these are not used for a long time. Plastic mulches such as those of white and green color allow photosynthetic active radiations (PAR) to pass through them, and in this way, weeds grow beneath these mulches, and at the same time, the dark-colored mulches do not allow these radiation to pass, and reduction of weed population occurs. Some weeds are so hardy that they can grow above the mulch surface, and sometimes, they penetrate through the plastic mulches also (Horowitz and Thomas 1994). Substitution of the plastic and fabric mulches is not only a time-consuming process but also an expensive method of mulching the soil surface. When we want to replace these mulches, they can even damage our crop of interest (Appleton et al. 1990).

Amongst different mulch materials, organic and inorganic are widely used in better reduction of weed control when these are used at adequate depth (Greenly and Rakow 1995) and these are not vulnerable to the compaction of soil (Einert et al. 1975). Inorganic mulches (gravel/stone mulch) when used at a 4-cm depth will avoid the colonization of weed species (Winkel et al. 1995). On the other hand, inorganic mulches provide better soil conditions such as moisture conservation and moderation of temperature but there is no light beneath these mulches and weed seeds who require light for germination do not germinate (Chalker-Scott 2007).

Organic mulches have various capabilities of controlling weed colonization. Compost is organic mulch which is full of nutrients, fertile the soil, and is not an excellent mulch to control the weeds (Maclean et al. 2003; Maynard 1998; Niggli et al. 1988). If this compost is not fully decomposed, then it will work as a seed bank of weeds and will be favorable for the establishment of perennial weed species. Mulch material which is used in a thin layer will sufficiently enhance the germination of weed seeds; otherwise, if it will be used in the thick layer, it will reduce the seed germination (Rokich et al. 2002).

Low-nutrient-rich organic mulches which are coarse in nature when applied in thick layers lessen the weeds more effectively than the herbicides (Cahill et al. 2005; Froment et al. 2000). Different crop residues (Davis 1994; Nath and Sarma 1992; Niggli et al. 1988) and forest-produced materials (Gardiner and Yeiser 1998) are used in un-composted forms and cause reduction of weed species in agricultural and landscape lands (Niggli et al. 1988). Most of the research studies suggest the use of sawdust as mulch for controlling of weed population in forest areas (Arthur and Wang 1999) or in container production system (Montano et al. 1977). Some other studies revealed that the thick layer of sawdust will be impervious for water and gas exchange (Stenn 2005).

Mulching reduce the light penetration below the surface and act as a barrier so there is no process of photosynthesis in weeds, and in this way, weeds cannot survive without glucose formation. It is the best strategy for controlling weeds of annual nature (Ahmad et 2020; Ahmad et al 2015). Intercultural practices in crop plants grown with mulches can be minimized due to a smaller number of weeds as mulch restricts weed growth. Polyethylene plastic sheets (as mulch) are reported to be more effective for weed control in cotton than in organic mulches. Reduction in weed density with increasing the amount of mulch was observed by (Ahmad et 2020; Ahmad et al 2015).

\section{Potential advantages of mulching in environment management}

Remediation of heavy metals

Heavy metals are injurious for both the animals and human health. Mulches are a good source for removal of these heavy metals from the soils (Chalker-Scott 2007). Leaves of arborvitae, eucalyptus, pine, and poplar are mostly used for removing these heavy metals from the soil solution (Salim and El-Halawa 2002). Using woodchips and compost in forest areas can make complex with the copper metal and convert it into the form which is not toxic for proper growth of crop plants (Kiikkila et al. 2002).

\section{Diminishing of pesticide use}

Mulch materials can decrease the stress level on plants and deal with different pathogens. Plants get resistance to weed attack and other harmful pests, and in this way, there will be no use of any type of fungicides, insecticides, and herbicides. Decline in the use of such chemicals will be in favor of farmers in the sense that no money is used for such chemicals and also the non-use of chemicals will be in favor of beneficial soil organisms' population and the environment (Chalker-Scott 2007).

\section{Visual enhancement by mulch}

The ground covers and tumbled grass mulches are good-looking and perform the function of soil protection against extreme climatic, biotic, and abiotic factors. Aesthetic improvement is not a technically quantified feature, but it shows the selection of the best mulch according to the landscape designs (Kader et al. 2019). Some fragrant ground covers and fresh mulch give pleasurable fragrance to the people. Smooth rock/stone mulch and soft ground covers also attract people due to their beauty in an aesthetic sense. However, some people do not like mulch materials; instead, they prefer bare 
soil because they consider the mulch as "messy" (Chalker-Scott 2007; Kader et al. 2019).

\section{Economic importance of mulching}

Whenever people use synthetic chemicals, fertilizers, and mulches, they estimate the cost and benefit which comes out from the investment. Mulch materials are not so costly as compared to other synthetic materials in terms of soil heath and the overall performance of crop plants. When we use mulches, there will be no cost on pesticide purchasing (Clemens and Starr 1985; Gardiner and Yeiser 1998) or on other methods of weed control (Gardiner and Yeiser 1998). Use of locally produced wood debris for the purpose of rehabilitation of damaged lands increases farmer income and enhances performance of crop growth and development (Munir et al. 1998). For the re-vegetation of roadsides, brush mulch was found to be the effective and the economical ones in urban areas (Rothwell 1978). The materials which can be locally available such as peat and timber harvest residues are economical and enhance the overall growth and development of crops (Van Nierop and White 1958; Kader et al. 2019).

\section{Comparative effects of mulched and un-mulched}

Raman et al. (2004) conducted a field experiment to observe the effects of various mulches on cotton growth-, yield-, and weed-related parameters. Different mulches used were as follows, i.e., sawdust, coir pith, water hyacinth, sugarcane trash mulch, and rice straw mulch. Very low density of weeds $\left(20 \mathrm{~m}^{-2}\right)$ was observed in sugarcane trash mulch followed by coir pith, water hyacinth, rice straw, and saw dust, and highest in control $\left(225 \mathrm{~m}^{-2}\right)$ treatment. More weed biomass was also reported in the control treatment $\left(157 \mathrm{~g} \mathrm{~m}^{-2}\right)$ followed by saw dust, rice straw, water hyacinth, and coir pith, and very less in sugarcane trash. In the same way, more weed control effectiveness was present in sugarcane trash (91\%), coir pith (84\%), water hyacinth (77\%), rice straw (65\%), and saw dust (52\%) in comparison to control treatment.

Ather et al. (2013) carried out a research study in field condition to check the effects of various treatments of weed control, i.e., wheat straw mulching, manual hoeing, acetochlor and pendimethalin + prometryne on weed population, its biomass production, and productivity of cotton. Wheat straw plots showed 59.25\% more efficiency of weed control than the rest of the treatments used in the experiment at maturity. All other growthand yield-related parameters were also high in mulched treatment in relation to other plots of experiment.

Motisham et al. (2013) found lower weed densities in treatments under sesbania and plastic mulch over the control treatment. Plastic mulch controls the weeds more efficiently compared to sesbania. It was concluded that less weed densities in plastic mulch were due to higher weed control efficiency of the plastic sheet. Weeds were mostly present in interplant spaces.

Vasilakoglou et al. (2006) conducted a field research study to evaluate the impact of different weed control measures on overall phonological stages of cotton. Three weed control methods were used namely as (i) herbicides, (ii) cereals as mulch, and (iii) inter-row cultivation. Findings of the research study showed that the germination and growth of weeds were very less under cereal mulch, herbicides, and inter-row cultivation as compared to control treatment. Cotton got vigorous growth under weed control methods in relation to control treatment. From the current study, it is concluded that usage of cereals as mulch is the effective strategy to reduce down the intensity of weeds and also to increase the cotton seed yield.

Ayyadurai (2011) conducted field experiment to find out the critical period of weed crop competition in cotton. Experiment included 12 different treatments (weedy and weed-free periods at 20,40, 60, 80, and 100 DAS and at harvest). Losses in seed cotton yield increased with increased duration of weed cotton competition and maximum loss (96.5\%) occurred with full-season competition followed by 100, 80, 60, 40, and 20 DAS. Srinivasalu and Rao (2000), Virk et al. (2002), and Bryson et al. (2003), and Latha (2005) also stated $85 \%$ yield losses in cotton due to weeds. Infestations 20 to 60 days after sowing were found to be the critical period of weed cotton competition. Significant increase in seed cotton yield was observed in plots that were kept weed free during first 80 DAS.

DilBaugh et al. (2010) used plastic mulching, manual weeding, and mechanical weed control methods to control the population of weeds and concluded that after 30 days of sowing mulched treatment reduced the weeds intensity in relation to un-mulched treatment about $100 \%$ of broad leaves weed and $95.8 \%$ of narrow leaves weed. Comparison of manual weeding or untreated treatment resulted in $89.7 \%$ broad leaves and $91.0 \%$ narrow leaves weed which were controlled in the manual weeding method. Mechanical weed control method + mulching controlled more broad leaves (10.3\%) and narrow leaves weed $(4.8 \%)$ as compared to the manual weeding.

Zamurrad et al. (2013) evaluated the effects of increasing rate of wheat straw mulch on the conservation of soil moisture content. Different rates of wheat straw mulches were used, i.e., (i) 4, (ii) 3 , (iii) 2 , and (iv) 1 tons $\mathrm{ha}^{-1}$ basis were used. From this research study, it was found out that with increasing the rate of wheat straw as mulch, maximum soil moisture was retained in relation to un-mulched treatment. The treatment of (i) 4 tons $\mathrm{ha}^{-1}$ showed minimum number of weed and very low 
weed biomass as compared to rest of the treatments used in the experiment. Same findings were also proposed by Garcia-Moreno et al. (2013). Robert et al. (2000) conducted a field experiment to study the effect of tillage and mulching on cotton yield and reported $35 \%$ higher lint yield in plots covered with wheat stubble mulch against the control (no mulch). Lower values of evaporation and higher values of water use efficiency were also recorded in mulched treatment over control.

Nasrullah et al. (2011) studied the effect of different mulched treatments $\left(M_{1}=\right.$ cultural mulch, $M_{2}=$ straw mulch, $M_{3}=$ plastic sheet, and $M_{4}=$ chemical mulch) and planting methods (single row planting, double row strip planting, ridge planting, and bed planting) on growth, yield, and water economy in cotton. Results indicated that among the mulches, various growth and yield attributes like plant height, leaf area index, crop growth rate, number of bolls per plant, and 100 boll weights were higher in plastic and minimum in straw mulch followed by cultural mulch and chemical mulch. Maximum biological yield (10040 kg/ha), seed cotton yield (3332 kg ha-1), harvest index (32.75), water saving (26.53\%), and water use efficiency $\left(5.04 \mu \mathrm{mol}\left(\mathrm{CO}_{2}\right) /\right.$ mmol $\left.\left(\mathrm{H}_{2} \mathrm{O}\right)\right)$ was also recorded in plastic sheet mulch. The maximum cotton yield and water saving was obtained in bed and furrow planting method with polythene plastic mulch.

Virdia and Patel (2000) evaluated the impacts of straw mulching and various irrigation methods on different growth stages and yield attributes of cotton crop and found that cotton crop under straw mulch produced more plant height, LAI, and high yield in comparison to un-mulched treatment used in the experiment. 21.4\% more cotton yield was attained in mulched treatment as compared to un-mulched treatment. It is mostly due to mulch materials which provide the plants with the best conditions of growing. ZongBin et al. (2004) carried out a field experiment on cotton to check out the effects of mulching on maintaining soil temperature and retaining moisture content in various soil profiles and also to see the impacts of mulching on the overall attributes and yield of cotton crop. In this experiment, it was found out that mulched material maintained the soil temperature at an optimum level of growth and conserved more moisture content as compared to un-mulched treatment. Mulched pots lower the soil temperature to about $14 \%$ and increased the moisture near to $3 \%$ in comparison to those without mulch (control) treatment. Mulch-treated cotton plants attained more photosynthetic rate, LAI, CGR, root growth, and all other yield-related values when compared with un-mulched treatment.

Jordan et al. (2010) studied the impacts of wheat straw mulching on soil water conservation and physical properties. Findings of the research study indicated that wheat straw used as mulch improved the physical and chemical properties of soil. Wheat straw mulch on decomposition increased the soil carbon content up to 10 $\mathrm{Mg} \mathrm{ha}^{-1}$ year $^{-1}$. Higher rates of mulch material improved the water holding capacity, infiltration rate, and moisture content of soil. Low rates of mulching have no such significant effects in relation to high-rate application but have some positive effects in relation to control treatment. Mulches can also reduce the soil erosion.

Similarly, Dahiya et al. (2007) conducted a field experiment to evaluate the impacts of mulch on soil temperature and soil water retention. Treatments used in the experiment were as follows: i.e., (i) normal irrigation, (ii) rotary hoeing, (iii) wheat straw as mulch, and (iv) wheat straw + rotary hoeing. Results of the study showed that mulches regulated the soil temperature and also reduced the water loss. Sampathkumar et al. (2006) investigated the effect of mulch (straw mulching and no mulching) with drip and conventional irrigation methods (drip, skip furrow, alternate furrow, full furrow, border strip, and check basin) on growth of cotton. The highest plant height $(105.8 \mathrm{~cm})$, leaf area index (5.088), and seed cotton yield $\left(2430 \mathrm{~kg} \mathrm{ha}^{-1}\right)$ was observed in mulched plots with drip irrigation. Kader et al. (2019) analyzed that mulches conserve the soil moisture and maintain the soil temperature. Mulches also provide the beautification in the environment and improve the growth and yield of various crop plants.

\section{Disadvantages of mulching}

\section{Lowering the soil $\mathrm{pH}$}

A few mulching materials are considered to acidify the soil; however, there is no proper scientific evidence about this acidification of soil due to mulching. Bark of some trees and wood chips are thought to be the main source of acidification. Most of the studies have dissimilar results by using mulch and describe that there are no harmful effects of mulches for soil acidification. A research study of pine (needles and bark) used as mulch had no significant effects on soil pH (Greenly and Rakow 1995). Bare soil is the most acidic soil than the inorganic mulch covered soil, and organic mulched soil is the least acidifying in all the treatments used in the research study (Iles and Dosmann 1999). A study of many years showed that organic mulches do not affect the $\mathrm{pH}$ of the soil, either it is acidic or alkaline (Pickering and Shepherd 2000). The application of woody materials in nursery production can produce acids such as phenolic acids due to the decomposition of the woody materials. However, in field conditions, woody materials have no or very low acidifying effect because of the localized production of acids. In the real world, there are no significant effects of mulches in causing acidity in soil (Chalker-Scott 2007). 


\section{Allelopathic effects}

Allelopathy refers to the inhibition in germination of seeds and growth of plants by the release of allelochemicals by the plants or sometimes by living or organic mulches. Allelochemicals control the weeds in crop plants. Juglonic acid is mostly isolated from the bark of black walnut and used in the inhibition of many weeds and non-desirable plants. This acid can also destroy the seedlings and shallow-rooted plants though it has no effect on established plants (Harris et al. 2004). Allelopathy caused the inhibition of seed germination by using an allelopathic compound in the laboratory research experiment (Duryea et al. 1999a), and some scientists consider the same way for the established crop plants. The seedlings or small seeds are most vulnerable to the mulch materials than the established plants. Research studies proved that when the extracts of different mulches like eucalyptus, acacia, and pine were used they reduced or totally suppressed the growth of various weed species which show an allelopathic effect of these mulches (Schumann et al. 1995). Narrow leaves plants like grasses are not affected as severe as the broad leaves plants or dicot species (Schumann et al. 1995). The contradictory results were also obtained in a research study conducted on rice crop (Lillaram and Rao 1980). Landscapes are affected by improper mulch application at the initial stage of landscaping, so to avoid the allelopathic effects, proper composting and woody mulch will ensure no harmful effects on landscapes (Chalker-Scott 2007).

\section{Competition for resources}

Competition refers to the struggle of the main crop for the same resources such as water, carbon dioxide, oxygen, nutrients, and physical space with the competing organism. The competition for the aforementioned resources could be of inter and intra specific. Both types of competitions are harmful for the growth and development of the main crop. Bedford and Pickering (1919) were the first to observe this phenomenon in gardens where garden floor was covered with grasses and trees were established. Grasses made a great loss to the trees in a competitive way. At last, this recovery was made by the removal of grasses to avoid the competition (Bedford and Pickering 1919). Turf and various grasses compete with the main plants (Kraus 1998; Fausett and Rom 2001). In a newly established crop, plants or tree turfs should be replaced by organic mulch. Organic mulches promote the rapid establishment of roots and avoid any competition and in return provide the nutrients on decomposition (Chalker-Scott 2007).

\section{Disease induction}

Diseased plants have mulch materials which have pathogens inside. If we use this type of mulches, then diseases will transfer to the healthy plants also. So, before using mulches, the mulch materials should be fully composted (Hoitink and Krause 1999). Sometimes, mulch materials are given a temperature treatment to destroy all the beneficial and harmful organisms contained in the mulch. Organic mulches which are available commercially are sterile in nature. We should focus on commercially available mulches to avoid pathogens (ChalkerScott 2007). Honey locust canker which is mostly used as mulch contains a number of pathogens which are harmful (Koski and Jacobi 2004). Some contradictory results were also obtained from different studies which showed that there is no transfer of diseases by using the diseased mulch as infected maple trees. When wood chips were made from this type of pathogenic trees, there was no spread of pathogen occurred in healthy trees (Dochinger 1956). In various research studies, it was observed that when mulches were made from such type of pathogenic trees there was occurrence of pathogens in healthy plants due to the reason that most of the pathogens dried out when mulches were made as shoestring root rot pathogen (Perez-Sierra et al. 2003). A research study of 6 years gave the similar results that when butt rot or canker diseased mulches were applied to the healthy plants there was no transmission of pathogen found. There was only evidence that when diseased Austrian pine foliage were used as mulch for the same species transmission of tip blight occurred (Jacobs 2005). Tip blight pathogen of Austrian pine did not affect any other crop plants. It was being referred that Austrian pine might be vulnerable to the pathogen. Epidemiology might be the reason of disease causing not the pathogenic source only (Chalker-Scott 2007).

Soils are another source of pathogen transmission. Pathogens or micro-organisms are always present in healthy soils. When the conditions of soil are poor or anaerobic, these pathogens become active and cause a great loss to the healthy crop plants (Foreman et al. 2002; Pair 1994). Properly composted mulch materials should be used always if un-composted materials would be used they will be the reason of pathogen transmission (Fraedrich and Ham 1982; Koski and Jacobi 2004; Niggli et al. 1988).

\section{Flammability}

There are different contradictions on the combustion of rapid-fire mulch. Some mulches combust rapidly than others. But there are some evidences of rapid flaming of farmyard wastes (Buggeln and Rynk 2002). Wood mulches do not generally combust fast. Research study was conducted to find out the rapid flammability of mulches (Steward et al. 2003), and it was drawn out that rubber mulch has the ability to combust fast than rest of the mulches used in the experiments. Whenever we 
apply mulch material, we should consider the flammability of mulches in regions where there is hazard of fire occurrence (Chalker-Scott 2007).

\section{Nitrogen insufficiency}

There is a misapprehension about the use of woody mulches that they cause nitrogen deficiency in plants when used in healthy crop plants or around the trees. The reason behind this is that the woody materials have high $\mathrm{C}$ to $\mathrm{N}$ ratio. The nitrogen is utilized by the micro-organisms leaving behind the carbon in soil which will cause the deficiency of nitrogen in soil, and this would be indicated by the chlorosis in plants (Chalker-Scott 2007).

Various research studies showed that use of woody mulch neither caused the nitrogen deficiency in soil nor the chlorosis in crop plants (Greenly and Rakow 1995; Pickering and Shepherd 2000). Contradictory findings also revealed that the woody mulch increased the nutrient level in soil and also in plant foliage (Arthur and Wang 1999; Pfammatter and Dessimoz 1997; Singh and Singh 1999; Szwedo and Maszczyk 2000).

\section{Pest infestation}

There is also a contradiction in the use of organic mulches. Some researchers found that organic mulches attract pests, and some scientists found that organic mulches are used as repellent of pests (Anderson 2002). Some species of Thuja are used as a chemical repellent for many pests like moths of clothes, killing cockroaches, and repelling ants, carpet beetles, and termites (Chalker-Scott 2007).

We commonly consider that woody mulches are magnets for termites attack. A lot of researches have been conducted on this fact with amazing results. One of the recent studies (Long et al. 2001) conducted on organic (wood) and inorganic (gravel) mulches and gave results that the termite activity was found higher beneath the gravel mulch as compared to the wood mulch. When organic mulches used in laboratory experiments were fed to termites, the death rate was so high. Similar results were also found in another study (Duryea et al. 1999b) where termites like the mulches which have higher nitrogen and phosphorus contents in them. So, in areas where the termites are the major pests, we should use the organic mulches which have low nutrient content in them (Martin and Poultney 1992). Landscape fabrics and black plastic mulch can reduce various pests (Duncan et al. 1992).

Mulches are dynamic in their ability to attract or repel pests and mammalian species as well. Many of the mulch materials by nature have the ability to repel mammals through their special characteristics of odors, thorns, and texture (Chaudhary 2003; Szwedo and Maszczyk 2000). Some of the mulches can attract pests such as rodents
Table 2 Selection of Mulches according to Ecological Conditions

\begin{tabular}{lll}
\hline Sr. No. & Ecological Situation & Mulches \\
\hline 1 & Rainy season & Perforated mulch \\
2 & Orchard and plantation & Thicker mulch \\
3 & Soil solarisation & Thin transparent film \\
4 & Weed control through solarisation & Transparent film \\
5 & Weed control in cropped land & Black film \\
6 & Sandy soil & Black film \\
7 & Saline water use & Black film \\
8 & Summer cropped land & White film \\
9 & Insect repellent & Silver colour film \\
10 & Early germination & Thinner film \\
\hline
\end{tabular}

who find shelter in dense-type mulches (Ferm et al.1994; Merwin and Stiles 1994; Siipilehto 2001).

\section{Weed infestation}

It is considered that some of the mulches are carrier agents of many weed seeds. The research study on this aspect is lacking. It is thought that composts and residues which are used as mulch if not properly decomposed carry the seeds of various weed species (ChalkerScott 2007). Good mulch has characteristics of deepness which inhibit the weeds and promote the healthy plants and soil. Research studies have proved that weed suppression is directly related to the depth of mulch (Foshee et al. 1996; McDonald et al. 1996). Organic mulches which are applied at a higher depth have the ability to reduce weed species as compared to those applied at shallow depths (Horowitz and Thomas 1994; Kuhns 1992; Zaragoza et al. 1995). Black plastic mulch is the cheapest and is easy to handle in field conditions than all other mulches. There are some general instructions for selecting plastic mulch in various ecological conditions as shown in Table 2.

\section{Conclusions}

Mulching with different materials can potentially conserve soil moisture, reduce evaporation losses, and suppress weed population. Different mulching exhibited significant impacts on growth, yield, and quality of various crops. The contradictions about the performance of mulching exist as adverse effects of mulching have been reported by different scientists. These disadvantages reported by different scientists are not as much dangerous in real field conditions, although the advantages of mulches are most dominant on these contradictions. However, it can be concluded from the literature that mulches are a cheap source to reduce weed populations and to conserve the soil moisture contents to a substantial level. Therefore, the properly managed mulching strategies could compensate the water requirement of 
crops in water deficit/drought conditions. Moreover, integrating the mulching system (wheat straw, cotton sticks, black plastic, maize straw) with partial root zone drying (PRD) could serve an efficient technique to enhance overall crop growth, development, and yield.

\section{Acknowledgments}

The authors thank the anonymous reviewers for providing constructive comments and suggestions.

\section{Author's contributions}

RI contributed to the conceptualization and analysis and wrote the paper. MASR, MV, MFS, MSZ, SA, and MT reviewed and edited the paper. IH, MUA, and MAN proofread the paper. All authors read and approved the final manuscript.

\section{Funding}

This research has not received any funding.

\section{Availability of data and materials}

All data generated or analyzed during this study are included in this published article.

\section{Ethics approval and consent to participate}

Not applicable.

\section{Consent for publication}

Not applicable.

\section{Competing interests}

The authors declare that they have no competing interests.

\section{Author details}

${ }^{1}$ Department of Agronomy, University College of Agriculture \& Environmental Sciences, The Islamia University of Bahawalpur, Bahawalpur, Pakistan. ${ }^{2}$ Center of Excellence for Climate Change Research/Department of Meteorology, King Abdulaziz University, Jeddah 21589, Saudi Arabia, Jeddah, Saudi Arabia. ${ }^{3}$ Department of Agronomy, University of Agriculture Faisalabad, Faisalabad, Pakistan. ${ }^{4}$ Liithuanian Center for Agriculture and Forestry (LAMMC), Kèdainiai, Lithuania.

Received: 29 October 2019 Accepted: 20 February 2020 Published online: 18 May 2020

\section{References}

Ahmad S, Raza MAS, Saleem MF, Zaheer MS, lqbal R, Haider I, Aslam MU, Ali M, Khan IH (2020) Significance of partial root zone drying and mulches for water saving and weed suppression in wheat. J.Anim.Plant.Sci. 30:154-162

Ahmad S, Raza MAS, Saleem MF, Zahra SS, Khan IH, Ali M, Shahid AM, Iqbal R, Zaheer MS (2015) Mulching strategies for weeds control and water conservation in cotton. J. Agric. Biol. Sci 8:299-306

Ahmed M, Baiyeri KP, Echezona BC (2013) Effect of coloured polyethylene mulch and harvesting stage on growth and yield of industrial sugarcane in Nigeria. Afric. J. Biotech. 12:10-18

Alami-Milani M, Amini R, Mohammadinasab AD, Shafaghkalvanegh J, Asgharzade A, Emaratpardaz J (2013) Yield and yield components of lentil (Lens culinaris Medick.) affected by drought stress and mulch. Int. J. Agric. Crop. Sci. 5:12-28

Anderson JT, Thorvilson HG, Russell SA (2002) Landscape materials as repellents of red imported fire ants. Southwest.Ento. 27:155-163

Anonymous (1957) Handbook on Mulches. Brooklyn Botanical Garden Records. 13:1-79

Ansari R, Marcar NE, Khanzada AN, Shirazi MU, Crawford DF (2001) Mulch application improves survival but not growth of Acacia ampliceps Maslin, Acacia niloticaL. and Conocarpuslancifolius L. on a saline site in southern Pakistan. Int. J. Rev 3:158-163

Appleton BL, Derr JF, Ross BB (1990) The effect of various landscape weed control measures on soil moisture and temperature, and tree root growth. J. Arboric. 16:264-268
Arora VK, Singh CB, Sidhu AS, Thind SS (2011) Irrigation, tillage and mulching effects on soybean yield and water productivity in relation to soil texture. Agric. Water. Manage. 98:563-568

Arthur MA, Wang Y (1999) Soil nutrients and microbial biomass following weedcontrol treatments in a Christmas tree plantation. J. Ame. Soc. Soil. Sci. 63: $629-637$

Ather MN, Idrees NM, Ayub M, Tanveer A, Mubeen K (2013) Effect of different weed control practices and sowing methods on weeds and yield of cotton. Pak. J. Bot. 45:1321-1328

Ayyadurai P, Poonguzhalan R (2011) Critical period of crop-weed competition in zero-till cotton. Indian. J. Weed. Sci. 43:228-230

Balasubramanian D, Arunachalam K, Arunachalam A, Das AK (2013) Effect of water hyacinth (Eichhornia crassipes) mulch on soil microbial properties in lowland rainfed rice-based agricultural system in Northeast India. Agric. Res. 2:246-257

Balvinder S, Gupta GN, Prasad KG (1988) Use of mulches in establishment and growth of tree species on dry lands. Ind. Fores. 114:307-316

Bedford HAR, Pickering PSU (1919) Science and Fruit Growing: Being an Account of the Results Obtained at the Woburn Experimental Fruit Farm Since Its Foundation in 1894. Macmillan.

Borst HL, Woodburn R (1942) The effect of mulching and methods of cultivation on runoff and erosion from Muskingham silt loam. J. Agric. Engin. 23:19-22

Bowen KL, Young B, Behe BK (1995) Management of black spot of rose in the landscape in Alabama. J. Plant. Dis. 79:250-253

Bryson CT, Reddy KN, Molin WT (2003) Purple nutsedge (Cyperus rotundus) population dynamics in narrow row transgenic cotton (Gossypium hirsutum) and soybean (Glycine max) rotation. Weed. Tech 17:805-810

Buban T, Helmeczi B, Papp J, Dorgo E, Jakab L, Kajati I, Merwin I, Polesny F, Muller W (1996) Olszak RW. IFP-compatible ground-cover management systems in a new-planted apple orchard. 19:263-267

Buggeln R, Rynk R (2002) Self-heating in yard trimmings: conditions leading to spontaneous combustion. Comp. Sci. Utiliz. 10:162-182

Burgess PJ, Nkomaula JC, Medeiros-Ramos AL (1997) Root distribution and water use in a four-year old silvoarable system. Agro.Forest.Forum. 8:15-18

Cahill A, Chalker-Scott L, Ewing K (2005) Wood-chip mulch improves plant survival and establishment at no-maintenance restoration site (Washington). Ecol. Resto 23:212-213

Calkins JB, Swanson BT, Newman DL (1996) Weed control strategies for field grown herbaceous perennials. J. Environ. Hortic. 14:221-227

Chalker-Scott L (2007) Impact of mulches on landscape plants and the environment - a review. J. Environ. Hortic. 25:239-249

Chaudhary RS, Patnaik US, Dass A (2003) Efficacy of mulches in conserving monsoonal moisture for the Rabi crops. J. Indian Soc. Soil Sci. 51:495-498

Clemens J, Starr RK (1985) Field establishment of container grown plants. I: effects of weed control. J. Environ. Manage. 21:257-261

Clifford ED, Massello JW (1965) Mulching materials for nursery seedbeds. Tree Planters' Notes 72:18-22

Crohn DM, Bishop ML (1999) Proximate carbon analysis for compost production and mulch use. Trans. ASAE 42:791-797

Dahiya R, Ingwersen J, Streck T (2007) The effect of mulching and tillage on the water and temperature regimes of a loess soil: experimental findings and modeling. Soil. Till. Res. 96:52-63

Davis JM (1994) Comparison of mulches for fresh-market basil production. J. Hortic. Sci. 29:267-268

Devasinghe DA, Premaratne UD, Sangakkara UR (2015) Impact of rice straw mulch on growth, yield components and yield of direct seeded lowland rice (Oryza sativa L.). Tropic. Agric. Res. 24:4-13

Dil Baugh M, Afzal MN, Raza I, Dupont PL (2011) Comparative study of different weeding methods on cotton crop under drip irrigation system. In World Cotton Research Conference-5, Mumbai, India, 7-11 (2011) (pp. 392-395). Excel India Publishers.

Dochinger LS (1956). New concepts of Verticillium wilt disease of maple. Phyto. 46: 467 (abstract).

Dong BB, Zhu HT, Zhong ZK, Ye GF (1996) Study on ecological effect of the forest land under-crop sowing and mulching of coastland soil by newly planted. Acta. Agric. Zheji. 8:154-157

Donnelly JR, Shane JB (1986) Forest ecosystem responses to artificially induced soil compaction. I. Soil physical properties and tree diameter growth. Canad. J. Res. 16:750-754

Downer J, Faber B, Menge J (2002) Factors affecting root rot control in mulched avocado orchards. Hortic.Techn. 12:601-605 
Downer J, Hodel D (2001) The effects of mulching on establishment of Syagrus romanzoffiana(Cham.)Becc.,Washingtonia robusta H. Wendl. and Archontophoenix cunninghamiana(H. Wendl.)H.Wendl. and Drude in the landscape. Sci. Hortic. 87:85-92

Duncan RA, Stapleton JJ, McKenry MV (1992) Establishment of orchards with black polyethylene film mulching: effect on nematode and fungal pathogens, water conservation, and tree growth. J. Nemato. 24:681-687

Duryea ML, English RJ, Hermansen LA (1999a) A comparison of landscape mulches: chemical, allelopathic, and decomposition properties. J. Arboric. 25: 88-96

Duryea ML, Huffman JB, English RJ, Osbrink W (1999b) Will subterranean termites consume landscape mulches? J. Arboric. 25:143-149

Dvorak P, Hamouz K, Kuchtova P, Tomasek J (2009) Study on the effect of mulching on potato production in organic farming. Zbornik Radova 44. Hrvatski i4 Medunarodni Simpozij Agronoma, Opatija, Hrvatska, 16-20 Veljace 2009, 59-62

Einert AE, Guidry R, Huneycutt H (1975) Permanent mulches for landscape plantings of dwarf crape myrtles. Amer. Nurseryman. 142:62-65

Entry JA, Strausbaugh CA, Sojka RE (2005) Compost amendments decrease Verticilliumdahliae infection on potato. Com. Sci. Utiliz. 13:43-49

Espi E, Salmeron A, Fontecha A, Garcia Y, Real Al (2006) Plastic films for agricultural applications. J. Plas. Film. Sheet. 22: 85-102

Fausett JB, Rom CR (2001) The effects of transitioning a mature high-density orchard from standard herbicide ground-cover management system to organic ground-cover management systems. Arkan. Agric. Exp. Stat. Res. Ser. 483:33-36

Ferm A, Hytonen J, Lilja S, Jylha P (1994) Effects of weed control on the early growth of Betulapendula seedlings established on an agricultural field. Scand. J. Forest. Res. 9:347-359

Fetri M, Ghobadi ME, Ghobadi M, Mohammadi G (2015) Effects of mulch and sowing depth on yield and yield components of rain-fed chickpea (Cicer arietinum L.). Jord.J. Agric. Sci 11(4)

Foreman GL, Rouse DI, Hudelson BD (2002) Wood chip mulch as a source of Verticilliumdahliae. Phyto. 92:S26 (abstract)

Foshee WG, Goff WD, Tilt KM, Williams JD, Bannon JS, Witt JB (1996) Organic mulches increase growth of young pecan trees. Hortic. Sci. 31:811-812

Fraedrich SW, Ham DL (1982) Wood chip mulching around maples: effect on tree growth and soil characteristics. J. Arboric. 8:85-89

Froment MA, Britt CP, Doney J (2000) Farm woodland weed control: mulches as an alternative to herbicides around newly planted oak Quercusrobur transplants. Asp. App. Biol. 20:81-86

Gan J, Zhu Y, Wilen C, Pittenger D, Crowley D (2003) Effect of planting covers on herbicide persistence in landscape soils. J. Environ. Sci. Tech. 37:2775-2779

García-Moreno J, Gordillo-Rivero Á, Zavala LM, Jordán A, Pereira P (2013) Mulch application in fruit orchards increases the persistence of soil water repellency during a 15-years period. Soil. Tillage Res. 130: 62-68.

Gardiner ES, Yeiser JL (1998) Converting stands of low-grade hardwoods to loblolly pine: stimulating growth and reducing costs through litter retention. South. J. App. Res. 22:148-155

Goulet F (1995) Frost heaving of forest tree seedlings: a review. New.Forests. 9:67-94

Green TL, Watson GW (1989) Effects of turf grass and mulch on establishment and growth of bare root sugar maples. J. Arboric. 15:268-272

Greenly K, Rakow D (1995) The effects of mulch type and depth on weed and tree growth. J. Arboric. 21:225-232

Griffiths W, Fairhurst TH (2003) Implementation of best management practices in an oil palm rehabilitation project. Int. J. Better. Crop. 17:16-19

Harris RW, Clark JR, Matheny NP (2004) Arboriculture: integrated management of landscape trees, shrubs, and vines, 4th edition. Prentice Hall, Inc, Upper Saddle River, NJ.578 pages.

Hashim S, Marwat KB, Saeed M, Haroon M, Waqas M, Shah F (2013) Developing a sustainable and eco-friendly weed management system using organic and inorganic mulching techniques. Pak. J. Bot. 45:483-486

Hoitink HAJ, Krause MS (1999) Control of nuisance and detrimental molds (Fungi) in mulches and composts. Special Circular Ohio Agric. Res. Dev. Ctr. 165: 66-69

Hopp H, Posey GB (1942) Evaluation of cork oak as a new farm tree crop in the southeastern United States. Bullitain.Ame. J. Eco. Sci. 23:p73

Horowitz M, Thomas JM (1994) Couverture du sol pour la gestion des mauvaises herbes (Soil cover for weed management). In Maitrise des adventices par voie non chimique. Communications de la quatrieme conference internationale IFOAM (pp. 149-54)
Houle G, Babeux P (1994) Fertilizing and mulching influence on the performance of four native woody species suitable for re-vegetation in subarctic Quebec. Canad. J. For. Res. 24:2342-2349

Hunt LO (1963) Evaluation of various mulching materials used to improve plantation survival. Tree Planters' Notes. 57:19-22

lles JK, Dosmann MS (1999) Effect of organic and mineral mulches on soil properties and growth of 'Fairview Flame $\mathrm{R}^{\prime}$ red maple trees. J. Arboric. 25: 163-167

Iqbal R, Muhammad ASR, Muhammad FS, Imran HK, Salman A, Muhammad SZ, Muhammad U, Imran H (2019) Physiological and biochemical appraisal for mulching and partial rhizosphere drying of cotton. J. Arid Land. 11:785-794

Jacobs KA (2005) The potential of mulch to transmit three tree pathogens. J. Arboric. 31:235-241

Jiang S, Gao X, Liang J, Wang P, Gao J, Qu Y, Feng B (2012) Effect of different furrow and mulched ridge on water moisture conversation and water saving of spring mung bean planted farmland. J. Agric. Sci. 4:132

Jordan A, Zawala LM, Gill J (2010) Effects of mulching on soil physical properties and runoff under semi-arid conditions in southern Spain. Catena. 15:77-85

Kacinski NA (1951) Sowing oak in micro depressions as a means of combating drought on light chestnut soils. Pocvoved. 10:585-603

Kader MA, Singha A, Begum MA, Jewel A, Khan FH, Khan NI (2019) Mulching as water-saving technique in dry land agriculture. Bulletin of the National Research Centre 43:1-6

Kamal I, Gelicus A, Allaf K (2012) Impact of instant controlled pressure drop (DIC) treatment on drying kinetics and caffeine extraction from green coffee beans. J. Food. Res. 1: 24.

Kiikkila O, Derome J, Brugger T, Uhlig C, Fritze H (2002) Copper mobility and toxicity of soil percolation water to bacteria in metal polluted forest soil. J. Plant. Soil. 238:273-280

Koski R, Jacobi WR (2004) Tree pathogen survival in chipped wood mulch. J. Arboric. 30:165-171

Kraus HT (1998) Effects of mulch on soil moisture and growth of desert willow. J. Hortic Technol. 8:588-590

Kudinov VI (1972) Sawdust instead of manure. Sadovodstvo. 12:p38

Kuhns $L J$ (1992) Efficacy and phytotoxicity of three landscape herbicides with and without a light mulch. Proc. Northeastern Weed Sci. Soc. 46:85-89

Kwambe XM, Masarirambi MT, Wahome PK, Oseni TO (2015) The effects of organic and inorganic mulches on growth and yield of green bean (Phaseolus vulgaris L.) in a semi-arid environment. Agric. Biol. JN Am. 6: 81-89

Lakatos T, Buban T, Muller W, Polesny F, Verheyden C, Webster AD (2000) Effectiveness of different groundcover materials to preserve soil water content in a young apple orchard. Acta.Hortic. 525:425-426

Lamont WJ (2005) Plastics: modifying the microclimate for the production of vegetable crops. Hortic. Technol. 15:477-481

Landis TD (1988) Management of forest nursery soils dominated by calcium salts. New.Forests. 2:173-193

Lightfoot DR (1994) Morphology and ecology of lithic-mulch agriculture. Geo. Rev. 25:172-185

Lillaram NT, Rao BW (1980) Leachings from eucalyptus leaves have no adverse effect on germination and growth of paddy. Current. Res. 9:202-203

Litzow M, Pellett H (1993) Influence of mulch materials on growth of green ash. J. Arboric. 9:7-11

Long CE, Thorne BL, Breisch NL, Douglass LW (2001) Effect of organic and inorganic landscape mulches on subterranean termite (Isoptera: Rhinotermitidae) foraging activity. J. Environ. Ento. 30:832-836

MacLean RH, Litsinger JA, Moody K, Watson AK, Libetario EM (2003) Impact of Gliricidiasepium and Cassia spectabilis hedgerows on weeds and insect pests of upland rice. J. Agric. Eco. Enviro. 94:275-288

Małecka I, Blecharczyk A (2008) Effect of tillage systems, mulches and nitrogen fertilization on spring barley (Hordeum vulgare). Agron. Res. 6: 517-529.

Martin PJ, Poultney R (1992) Survival and growth of clove seedlings in Zanzibar. Effects of mulching and shade crops. J. Tropic. Agric 69:365-373

Masaka J, Dera J, Muringaniza K (2019) Dry land grain Sorghum (Sorghum bicolor) yield and yield component responses to tillage and mulch practices under subtropical African conditions. Agric. Res. 1-9

Matthews B (1948) Report on sawdust. New Zealand Gardener. 4:391-394

Maynard AA (1998) Utilization of MSW compost in nursery stock production. J. Com. Sci. Utiliz. 6:38-44

McCambridge WF, Morris MJ, Edminster CB (1982) Herbage production under ponderosa pine killed by the mountain pine beetle in Colorado 
(Vol.416). USDA Forest Service, Rocky Mountain Forest and Range Experiment Station.

McDonald HG, Smith JM, Britt CP (1996) The effectiveness of organic mulches on weed control in farm woodlands. Asp. App. Bio. 44:63-68

Megahan WF (1974) Deep-rooted plants for erosion control on granitic road fills in the Idaho Batholith (Vol. 161). US Department of Agriculture, Forest Service, Intermountain Forest and Range Experiment Station.

Merwin IA, Stiles WC (1994) Orchard groundcover management impacts on apple tree growth and yield, and nutrient availability and uptake. J. Amer. Soc. Hort. Sci. 119:209-215

Miles M (2005) Identification, pest status, ecology and management of the green mirid, a pest of cotton in Australia.PhD thesis, University of Queensland, St Lucia, Australia.

Mishra AK, Bhowmik AK, Banerjee SK (1996) Effect of mulches on growth of tree species on fly ash.J. Environ. Eco. 14:411-414

Mohtisham A, Ahmad R, Ahmad Z, Aslam MR (2013) Effect of different mulches techniques on weed infestation in aerobic rice (Oryza sativa L.). Ame-Eur. J. Agric. Environ. Sci. 13: 153-157

Montague T, Kjelgren R (2004) Energy balance of six common landscape surfaces and the influence of surface properties on gas exchange of four containerized tree species. Sci. Hortic. 100:229-249

Montano JM, Fisher JT, Cotter DJ (1977) Sawdust for growing containerized forest tree seedlings. Tree Planters' Notes 28:6-9

Moursy FS, Fatma A, Mostafa N, Solieman Y (2015) Polyethylene and rice straw as soil mulching: reflection of soil mulch type on soil temperature, soil borne diseases, plant growth and yield of tomato. Glo. J. Adv. Res 2:1496-1519

Munir AD, Majid NM, Abdoland I, Khan GS (1998) Effects of mulching on the growth of interplanted Acacia mangiumon sandy tin-tailings in Peninsular Malaysia. Lyallpur Akhbar. 65:3

Naklang K, Whitbread AM, Konboon Y, Suriya-Arunroj D, Blair GJ, Lefroy RDB (1999) The management of pre and post-legume crops, fertilizers and plant residues on rice yields and soil carbon in a flooded rice cropping system, pp. 51-57. In: A.M. Whitbread and G.J. Blair (eds.), integrated nutrient management in farming systems in Southeast Asia and Australia: Proceedings of an International Workshop. National Agricultural Research Centre, Vientiane, Laos. April 21-22, 1999.

Nalayini P (2007) Poly-mulching a case study to increase cotton productivity. Senior scientist, Central Institute for Cotton Research, Regional Station, Coimbatore.

Nasrullah M, Khan MB, Ahmad R, Ahmad S, Hanif M, Nazeer W (2011) Sustainable cotton production and water economy through different planting methods and mulching techniques. Pak. J. Bot. 43:1971-1983

Nath JC, Sarma R (1992) Effect of organic mulches on growth and yield of Assam lemon (Citrus limonBurm). Hortic. J. 5:19-23

Ngouajio M, McGiffen ME (2004) Sustainable vegetable production: effects of cropping systems on weed and insect population dynamics. Acta.Hortic. 638:77-83

Niggli U, Weibel FP, Potter CA (1988) Unkrautregulierung in einerDauerkulturdurchBodenbedeckungmitorganischenMaterialien (Weed control in a perennial crop using an organic mulch). Zeitschrift fur Pflanzenkrankheiten und Pflanzenschutz 11:357-365

Oliveira MT, Merwin IA (2001) Soil physical conditions in a New York orchard after eight years under different groundcover management systems. J. Plant. Soil. 234:233-237

Pair JC (1994) Adaptability of evergreen rhododendrons to the great plains as influenced by landscape exposure. Amer. Rho. Soc. J. 48:69-72

Perez-Sierra A, Laflamme G, Berube JA, Bussieres G (2003). Preliminary study on the survival and spread of Armillariamelleain mulches in gardens. Information Report Laurentian Forestry Centre, Quebec Region, Canadian Forest Service, No. LAU-X-126: 436-438.

Pfammatter W, Dessimoz A (1997). Influence de l'irrigationetde la couverture du sol sur le developpementet le rendement de jeunespommiers (Influence of irrigation and ground cover on development and yields of young apple trees). Revue Suisse de Viticulture, d'Arboricultureetd'Horticulture 29: 301-304

Pickering JS, Shepherd A (2000) Evaluation of organic landscape mulches: composition and nutrient release characteristics. Arboric. J. 23:175-187

Pirone PP (1941) Freak weather damages trees and shrubs. New.Jersey. Agric. 23:3

Raman R, Kuppuswamy G, Krishnamoorthy R (2004) Effect of mulching on the growth and yield of cotton. J. Ecobiol. 16:275-278

Rathore AL, Pal AR, Sahu KK (1998) Tillage and mulching effects on water use, root growth, and yield of rain-fed mustard and chickpea grown after lowland rice. J. Sci. Food. Agric. 78:149-161
Ringe JM, Graves DH (1990) Mulches derived from wood: an economic comparison of two materials used to reclaim surface mines. J. Forest. Prod. 40:35-38

Robert JL, Baumhardt RL, Hicks SK, Heilman JL (2000) Soil and plant water evaporation from strip-tilled cotton: measurement and simulation. Agro. J. 86:987-994

Rokich DP, Dixon KW, Sivasithamparam K, Meney KA (2002) Smoke, mulch, and seed broadcasting effects on woodland restoration in Western Australia. J. Rest. Eco. 10:185-194

Rothwell RL (1978) Erosion control on forest roads. Agriculture and Forestry Bulletin, University of Alberta. 1:29-32

Russell JC (1939) The effect of surface cover on soil moisture losses by evaporation.Amer. Soil. Science Society 4:65-70

Saikia US, Kumar A, Das S, Pradhan R, Goswami B, Wungleng VC, Ngachan SV (2014) Effect of mulching on microclimate, growth and yield of mustard (Brassica juncea) under mid-hill condition of Meghalaya. J. Agromet. 16:144

Salim R, El-Halawa RA (2002) Efficiency of dry plant leaves (mulch) for removal of lead, cadmium and copper from aqueous solutions. Pro.Safe. Environ. Pro. 80: 270-276

Samarappuli L, Yogaratnam N (1984) Some aspects of moisture and soil conservation in rubber plantations. pp. 529-543. In: Proceedings of the International Rubber Conference. 75 Years of rubber research in Sri Lanka, September 1984, Colombo. Volume 1, Part 2. Rubber Research Institute of Sri Lanka: Agalawatta, Sri Lanka.

Sampathkumar T, Krishnasamy S, Ramesh S, Prabukumar G, Gobi R (2006) Growth, nutrient uptake and seed cotton yield of summer cotton as influenced by drip, surface irrigation methods and mulching practices. Res. J. Agric. Biol. Sci. 2:420-422

Samra JS, Singh SC (1998) Evaluation of an Acacia niloticabased silvipasture system on degraded land of Shivalik foothills. Ind. J. Soil. Cons. 26:226-233

Sartz RS (1963) Water yield and soil loss from soil-block lysimeters planted to small trees and other crops. USFS Research Paper LS-6, St. Paul, MN, 23 pp.

Schahbazian N, Iran-Nejad H (2006) The effects of different mulch types and irrigation intervals on cotton yield. Die. Bodenk. 57:765-766

Schales F (1990) Agricultural plastics use in the United States. Proceedings of the $11^{\text {th }}$ International Congress of Plastics in Agriculture, 54-56.

Schumann AW, Little KM, Eccles NS (1995) Suppression of seed germination and early seedling growth by plantation harvest residues. South.Afric. J. Plant. Soil. 12:170-172

Seckler DW, Tejwani KG (1983) Effect of sand and gravel mulching on moisture conservation for tree saplings. J. Tree. Sci 2:20-23

Shogren RL (2001) Biodegradable mulches from renewable resources.J. Sus. Agric 16:33-47

Siipilehto J (2001) Effect of weed control with fiber mulches and herbicides on the initial development of spruce, birch and aspen seedlings on abandoned farmland. Silva.Fenn. 35:403-414

Singh AK, Saggar S (1997) Effectiveness of mulches and organic moisture retainer on growth of Dalbergiasissooin a highly degraded land. Indian. Agric. 41: 209-216

Singh AK, Singh RB (1999) Effect of mulches on nutrient uptake of Albiziaproceraand subsequent nutrient enrichment of coal mine overburden. J. Tropic. Sci. 11:345-355

Singh SB, Pramod K, Prasad KG, Kumar P (1991) Response of Eucalyptus to organic manure mulch and fertilizer sources of nitrogen and phosphorus. Van.Vig. 29:200-207

Smith LJ, Skroch WA (1995) Turf herbicide injury to landscape trees as influenced by mulch. J. Environ. Hortic. 13:60-63

Smith MW (2000) Cultivar and mulch affect cold injury of young pecan trees. J. Amer. Pomo. Soc. 54:29-33

Spaulding P, Hansbrough JR (1943) The needle blight of Eastern white pine. USDA Bureau of Plant Industry, 2 pp.

Srinivasalu G, Rao AS (2000) Effect of sequential application of herbicides on weed management in cotton. 71-74. In: Proceedings of Symposium on Challenges in Agronomic Crop Management in early 21st Century, Society of Agronomists, Hyderabad, May 24-25.

Stenn H (2005) Woody mulch research review, professional users and product availability surveys.Seattle Public Utilities, Seattle, WA.

Steward LG, Sydnorand TD, Bishop B (2003) The ease of ignition of 13 landscape mulches. J. Arboric. 29:317-321

Stinson JM, Brinen GH, McConnell DB, Black RJ (1990) Evaluation of landscape mulches. Florida. Stat. Hortic. Soc. 103:372-377 
Sun D, Dickinson G, Bragg A (1994) The establishment of Eucalyptus camaldulensis on a tropical saline site in north Queensland. Australia. J. Agric Eco. Environ. 48:1-8

Szwedo J, Maszczyk M (2000) Effects of straw-mulching of tree rows on some soil characteristics, mineral nutrient uptake and cropping of sour cherry trees. J. Fruit. Orna.Plant. Res. 8:147-153

Tan D, Fan Y, Liu J, Zhao J, Ma Y, Li Q (2019) Winter wheat grain yield and quality response to straw mulching and planting pattern. Agric. Res. 1-5

Tanavud C, Kheowvongsri P, Yongchalermchai C, Leowarin W, Densrisereekul O, Bennui A, Muraseand J, Kimura M (2001) Effects of land use patterns on soil and water quality in Khlong U-Taphao Basin. Thai. J. Agric. Sci. 34:15-31

Tilander Y, Bonzi M (1997) Water and nutrient conservation through the use of agro-forestry mulches, and sorghum yield response. J. Plant. Soil. 197:219-232

Tisserat N, Kuntz JE (1984) Root deterioration of black walnut seedlings during overwinter storage in Wisconsin. Tree Planters'Notes. 35:31-35

Turchetti T, Maresi G, Nitti D, Guidotti A, Miccinesi G (2003) II mal dell'inchiostronelMugello (Fi): danniedapprocci di difesa (Chestnut ink disease in the Mugello area: damage and control). Monti e Boschi. 54:22-26

Van Nierop ET, White DP (1958) Evaluation of several organic mulching materials on a sandy loam forest nursery soil. J. Fore. 56:23-27

Vasilakoglou K, Dhima I, Eleftherohorinos LA (2006) Winter cereal cover crop mulches and inter-row cultivation effects on cotton development and grass weed suppression. Agro. J. 98:1290-1297

Virdia HM, Patel PG (2000) Effect of methods and scheduling of irrigation and mulching on yield of cotton. Guj. Agric. Uni. Res. J. 26:6-11

Virk J, Singh SD, Tripathi HP (2002) Growth and yield of cotton as influenced by herbicides alone or in combination with interculture. Pesticides. 16:21-25

Walsh BD, Salmins S, Buszard DJ, MacKenzie AF (1996) Impact of soil management systems on organic dwarf apple orchards and soil aggregate stability, bulk density, temperature and water content. Canad. J. Soil. Sci. 76: 203-209

Watson GW (1988) Organic mulch and grass competition influence tree root development. J. Arboric. 14:200-203

Watson GW, Kupkowski G (1991) Effects of a deep layer of mulch on the soil environment and tree root growth. J. Arboric. 17:242-245

Wilen CA, Schuch UK, Elmore CL (1999) Mulches and sub-irrigation control weeds in container production. J. Environ. Hortic. 17:174-180

Winkel VK, Medrano JC, Stanley C, Walo MD (1995) Effects of gravel mulch on emergence of galleta grass seedlings. General Technical Report Intermountain Research Station, USDA Forest Service INTGTR-315:130-134

Wood CB, Smalley TJ, Rieger M, Radcliffe DE (1994) Growth and drought tolerance of Viburnum plicatumvar. tomentosum'Mariesii' in pine barkamended soil. J. Amer. Soc. Hortic. Sci. 119:687-692

Woods FW, Hay RL, Irwin GH (1979) Summer planting on strip mines successful. Tree Planters' Notes 30:22-23

Xing NQ, Zhang YQ, Wang LX (2003) The study on dry-land agriculture in North China.(In Chinese.) Chinese Agriculture Press, Beijing.

Yang YM, Liu XJ, Li WQ, Li CZ (2006) Effect of different mulch materials on winter wheat production in desalinized soil in Heilonggang region of North China. J. Zhej. Uni. Sci. 7:858-867

Yobterik AC, Timmer VR (1994) Nitrogen mineralization of agro-forestry tree mulches under saline soil conditions.In: R.B. Bryan (ed.) Adv. Geo-eco. 27:181-194

Zajicek JM, Heilman JL (1994) Transpiration by crape myrtle cultivars surrounded by mulch, soil, and turfgrass surfaces. J. Hortic. Sci. 26:1207-1210

Zamurrad M, Tariq M, Shah FH, Subhani A, ljaz M, Iqbal MS, Koukab M (2013) Performance based evaluation of groundnut genotypes under medium rainfall conditions of Chakwal. J. Agri-Food. Applied. Sci. 1: 9-12.

Zaragoza C, Moya S, Martinez G (1995) Effects of mulches based on pine bark and pruning residues in a fruit orchard), pp. 283-290.Proc. 1995 Congress Spanish Weed Sci. Soc., Huesca, Spain.

Zink TA, Allen MF (1998) The effects of organic amendments on the restoration of a disturbed coastal sage scrub habitat. J. Restor. Eco. 6:52-58

ZongBin M, LingLi L, WeiPing F, DeYi X, TieGang Y (2004) Effect of wheat straw mulching on soil temperature, moisture and growth and development of summer cotton. J. Henan Agric. Uni. 38:379-383

\section{Publisher's Note}

Springer Nature remains neutral with regard to jurisdictional claims in published maps and institutional affiliations.

\section{Submit your manuscript to a SpringerOpen ${ }^{\circ}$ journal and benefit from:}

- Convenient online submission

- Rigorous peer review

- Open access: articles freely available online

- High visibility within the field

- Retaining the copyright to your article

Submit your next manuscript at $\boldsymbol{\nabla}$ springeropen.com 